\title{
Social Representation of Non-Academic Work in Mexico in the Light of Cultural Artefacts
}

\author{
Ute Clement ${ }^{1}$, Paola García Fuentes ${ }^{2}$, Stefan Gold ${ }^{2}$, \\ Claudia Hunink ${ }^{\star 1}$, Lydia Raesfeld ${ }^{3}$ \\ ${ }^{1}$ Universität Kassel, Institut für Berufsbildung, Henschelstr. 2, 34127 Kassel, Germany \\ ${ }^{2}$ Universität Kassel, Faculty of Economics and Management, Kleine Rosenstr. 3, \\ 34117 Kassel, Germany \\ ${ }^{3}$ Universidad Autónoma del Estado de Hidalgo, Carretera Pachuca-Actopan Km. S/N, \\ 42084 Pachuca de Soto, México
}

Received: 27 October 2020, Accept: 20 May 2021

\begin{abstract}
Context: Technical and Vocational Education and Training (TVET) has attracted increasing interest in recent years due to its potential to address productivity and equity challenges, such as better employment prospects, as outlined in the United Nations Sustainable Development Goals (SDGs). Despite the potential of such programmes, the enrolment rate in vocational training at upper secondary level in Mexico is $38.2 \%$, i.e. below the Organisation for Economic Cooperation and Development (OECD) average of $45.7 \%$. This raises the question of possible reasons for the low enrolment rate.

Approach: Based on the assumption that attitudes towards non-academic work are culturally anchored in Mexican society, which also shapes the educational and career aspirations of younger generations, the project named Cultural Practice of Non-academic Work in Mexico (KuPraMex), funded by the German Federal Ministry of Education and Research (BMBF), investigates social representations of non-academic work in Mexico. This is done through the analysis of artefacts such as films, murals, etc., as these are part of the tangible culture of a society. As materialised products of human activities or cultural practices, artefacts can be understood as objectifications of social relations and conditions. Therefore, in this context, it is assumed that through the analysis of cultural artefacts, a deeper understanding of how nonacademic work is thought, felt, and valued in Mexican society will emerge.
\end{abstract}

*Corresponding author: chunink@uni-kassel.de 
Findings: It has been found that the topic on non-academic work is often associated with informality. Moreover, the representations and narratives in cultural artefacts often show that non-academic work, apart from office work, is physically challenging but cognitively undemanding. In terms of access to a company, social networks seem to have enormous relevance. Hierarchies seem rigid and opportunities for promotion limited. However, narratives with more positive attributions regarding non-academic work can also be identified, which state that young people experience a habitus transformation through work.

Conclusion: Nevertheless, non-academic work in Mexico seems to lack prestige, which may affect young people's educational and career aspirations and choices. This could mean that those who can afford it prefer to pursue a career in tertiary education rather than opt for a TVET programme. At the macro level, the mentioned lack of prestige could hamper attempts to offer such programmes.

Keywords: Vocational Education and Training, VET, Non-Academic Work, Artefacts, Social Representation, Mexico, Culture

\section{Non-Academic Work From a Culturally Informed Perspective}

Educational politics often seem to target mainly academic education and university degrees. However, the productivity of a society also - and literally - lies in the hands of blue-collar workers and administrative staff. In this article, labour in production, agriculture, health, tourism and other services or administration which require competences not acquired in universities, will be subsumed under the umbrella term of non-academic work. There is a lot of evidence that Technical and Vocational Education and Training (TVET) investment pays off, not only in terms of social effects and increased efficiency of economies, but also in terms of individual wages (Almeida et al., 2015; Icardi, 2021; OECD, 2019). Nevertheless, when it comes to formal educational and career aspirations, non-academic labour is sometimes perceived as a second-best choice. Young people and their families in many South American countries show little inclination for vocational training and artisan careers. Also, for Mexico, the Organisation for Economic Cooperation and Development (OECD, 2019) reports that despite the potential of TVET programmes mentioned above, the enrolment rate in vocational programmes at upper secondary level is only $38.2 \%$, below the OECD average of $45.7 \%$. This phenomenon, sometimes labelled as white-collar syndrome, may lead to serious mismatches between educational systems and labour market, and hence has severe repercussions for economies, companies, and individuals (Almeida et al., 2015).

Often, biographical decisions are not very rational. We visualise our potential future based on fantasies, experiences and emotions, rather than figures and empirical projections. If educators and policymakers want to understand (and perhaps influence) educational decisions, 
it is therefore necessary to understand culturally shaped and therefore irrational-seeming motives that underlie the decisions. This is especially important in a time when the power of family traditions in career choices seem to diminish in many communities.

The culturally anchored picture of normal work helps people to guide their career decisions and to coordinate their educational efforts. Normality assumptions provide the foundation of how people look for work, integrate themselves into the world of labour, and submit to work requirements or defend themselves against unreasonable demands. In this way, the normality assumption of work is both the result of social action, and its guideline. Such cultural patterns are "rooted in societies" (Becker, 2004; Giesecke \& Wotschack, 2009), even though - as social phenomena - they can also be the subject of changes and social dynamics (with regard to Germany cf. e.g. the contributions to Behringer, 2004; Brose \& Wohlrab-Sahr, 2018 or Voß, 1998).

Assumptions about normality regarding labour are not only directed to specific working places or jobs (i.e. referring to the question of how it is to work as a plumber, electrician or nurse), they are also based on institutionalised structures and rules of labour markets. Our beliefs regarding the quality of a workspace, income, career chances, etc. depend on how normality of workspaces, income and career chances are constructed and passed on in institutionalised surroundings.

However, in the study presented here on social representations of work in Mexico which is part of the project entitled Cultural Practice of Non-Academic Work in Mexico (KuPraMex) supported by the German Ministry of Education and Research (BMBF), we are keen to dig even deeper and to find out more about thoughts, beliefs, and emotions, which are culturally bound to certain non-academic jobs. We want to understand how people of the cultural context of Mexico perceive non-academic work. In order to do so, in a first step we analyse cultural artefacts such as films, murals, etc. because they belong to tangible culture of a society. We want to better understand the central core of social representations in Mexican society, especially of the youth, regarding non-academic work.

What contributions can such a culturally informed perspective bring to comparative vocational education research on a scientific level? On first sight, this question does not seem very reasonable nowadays. Comparative vocational education research has been withdrawing from cultural topics since the turn of the millennium. In view of the globalisation of population movements and production sites, it seems more appropriate to focus less on conditions and more on the results of vocational education and training: Competencies. Even before experts in Europe started to design, discuss, and coordinate a European competency framework, systems for the recognition of previously acquired competences and their classification into competency frameworks had been created in Chile, Argentina, Colombia and Mexico. 
The reasoning was compelling: If it no longer matters in which institution and in what period of time a competence is acquired, but only what a person knows and can do, then people could be appropriately allocated across system boundaries. Moreover, if competencies could become the one and most important currency in labour market, social borders - for example, between general and vocational education system or between informal and formal education could also be overcome.

Despite its merits, the debates about competency frameworks had a completely unintended effect: Comparative research into vocational education came out of focus due to the concentration on the output. In the 1980s and 1990s, there had been endeavours to analyse foreign systems of vocational education for shedding new light on one's own (see the fundamental considerations at Lauterbach, 1994; studies such as Georg, 1997; or the systematisation at Deißinger \& Frommberger, 2010). As well, research in Latin America such as Arnold (1989), Clement (1999a), Greinert (1997), Lehner (1994), Wallenborn (2001) and Wolf (2011), was barely followed up. Studies on the informal sector (for a summary see Bayón, 2008) were overshadowed by the promise that the competence orientation would overcome even these barriers between formal and informal sectors.

Since the euphoria regarding the competence frameworks has been slowly subsiding (Clement, 2016), comparative vocational researchers have been re-establishing the earlier traditions. For Latin America, more recent research restoring these traditions comprise, for example Clement and Oelsner (2016), Oelsner and Richter (2015), Schoenstedt-Maschke (2013), Sevilla (2017) and more specifically for Mexico, for example Cáceres-Reebs and Schneider (2013) as well as Wiemann (2018).

Nevertheless, the criticism of competence orientation has also left its mark on comparative educational research. If training and employment systems are analysed by describing institutional structures (types of school, certificates, authorisation systems) and empirical data (labour market, education), something essential is missing - this has become increasingly clear. Sociological concepts such as the description of labour market regimes and governance, or psychological approaches, for example on professional identity or self-concept, indicate that there are also social connections beyond the level of institutions and structures that make the interaction between education and the labour market work. The complex coordination between educational and career aspirations and selection, labour market and allocation, demand and supply, norms, interests and emotions, state, private and individual action, etc. cannot be understood only by the precise description of structures. People do not make decisions (e.g. when choosing a profession, selecting personnel, etc.) as the bottom line of a structure. Rather, they have socially shaped perceptions, normality assumptions, expectations and values based on their own culture, in which such structures (often shortened) are condensed and reflected, but not exhausted. In this way, a culturally informed perspective is highly promising for analysing non-academic work in a country like Mexico. 


\section{Context of Young People in Mexico}

Both conceptions of non-academic work and work itself are social constructions that develop in a socio-historical context. Currently, this topic has gained relevance in academic circles and in the world of work due to the profound transformations in organizational and technological changes that have been taking place. The causes of these changes are attributed to policies that favoured deregulation, flexibilization and the incorporation of new technologies. As a consequence of a successive implementation of the neoliberal model, young people are not only prevented from accessing an occupation or professional profile, but they enter the world of work in a globalized market characterized by uncertainty and instability and are exposed to high rates of unemployment and job insecurity today.

The choice of young people as the unit of analysis responds to the need not to fall into universalism when approaching the relationship between subjects and work. Youth is considered as a socio-cultural category, of which duration and characteristics are determined by the respective society. "[Y]outh and age are not self-evident data but are socially constructed, in the struggle between the young and the old" (Bourdieu, 1993, p. 95). Youth has become a focus of interest in social studies, and it represents a particularly interesting object of investigation in a society in which social representation of non-academic work seems to be reformulating. Whereas young people suffer from exclusion from parts of the labour market, many of them are forced to work at early age, also as a result of the conditions of poverty.

The main people affected by unemployment in Mexico are young people. Official numbers show that the majority of those who cannot find work are between 14 and 29 years. One tenth of young people are unemployed. The problem is aggravated by the fact that one out of four people in the country is young and young people represent one third of the economically active population (EAP, calculated at 47 million 131 thousand 536 individuals) (INEGI, 2020). Due to low economic growth and insufficient labour market policies, the country could not effectively incorporate youth into the formal labour market. This leads to a loss of social and economic capital, and to young people being forced to work at young age and without social and labour protection, making them subject to precarious conditions.

This makes young people face various exclusion situations: Exclusion from the labour market due to the barriers they find; economic exclusion due to their inability to generate income; institutional exclusion due to the lack of support from state programs; cultural exclusion due to the inability to live in accordance with socially accepted norms and values. In summary, working conditions can be assumed to have an impact on the significations of non-academic work among young people, taking into account that work is an activity that generates significance. The meanings attributed to work vary from one society to another and over time, since they are determined by historical, social and cultural variables. 


\section{Non-Academic Work and its Social Representation as Fields of Investigation}

Economic research points out that labour markets and corporate actions should also be analysed against the background of socio-cultural differences. For example, Sagiv and Schwartz (2007) formulated that organisations are shaped by the societies around them, the personal values and priorities of their members, and the type of core tasks of the organisation. Cameron and Quinn (2006) developed their "Competing Values Framework" based on empirical studies on the characteristics of organisational culture and extensive factor analyses. Wolf et al. (2011) proposed an analytic scheme specifically related to the relationship between vocational training and the labour market. It describes six dimensions (labour regime, labour law, technology, collective actors, social security, and institutional order), which helps to describe the work-cultural background of employment qualification.

Research and practice have acknowledged the importance of working individuals for organisational and business success for a long time. On the research side, evidence exists that a committed workforce that is more likely to engage in learning leads to improved business performance (Cillo et al., 2019), and other organisational performance indicators such as decreased turnover intention (Santhanam \& Srinivas, 2019). Work identity, job satisfaction, competence acquisition, as well as commitment and engagement of blue-collar workers are critically connected to the societally shared and culturally anchored picture of their jobs as well as the employment-structuring institutions such as recruitment regimes, remuneration schemes and control systems (Pries, 2010).

In this light, the subject of analysing social representations of non-academic work in Mexico through various forms of cultural artefacts gains its particular relevance not only for TVET research but also organisational research and business practice. Understanding the cultural and institutional underpinning of blue-collar jobs may help workers engage in techniques of self-affirmation (Elsbach, 2003) that enhance their cognitive performance and their decision-making (Hall et al., 2014). At the same time, knowledge about the ideas and cultural significance workers hold about the jobs they carry out may guide organisations and managers in facilitating so-called holding environments; such holding-environments provide psychological safety and may help workers cope with threats of financial insecurity, harassment and other assaults to a person's integrity and dignity (Kahn, 2001). Finally, cultural analyses of blue-collar jobs, together with the work relations they are embedded in, may inform effective control and appraisal systems that lead to worker motivation and empowerment rather than a dichotomy of compliance or resistance (Curchod et al., 2019), both of which do not entail worker engagement in their jobs. 


\section{Social Representations and the Relevance of Cultural Artefacts}

The aim of the BMBF-funded project KuPraMex is to find out which collectively shared images, conceptions, ideas and knowledge concerning non-academic work dominate in Mexican society, composed of individuals of all ages. However, the focus in this context is primarily on young people who are before or in transition to working life and must make educational and career choices in line with their collectively shared ideas, images, values and cultural significance.

It is precisely these collectively shared ideas, images, meanings and values that are closely associated with the concept of culture. The first definition of the term culture at the end of the 19th century, made by Tylor (1891, p. 1), states that culture "in the broad ethnographic sense, is that complex whole which includes knowledge, beliefs, art, morals, law, customs, and all other habits and capacities acquired by man as a member of society", i.e. the tangible and intangible manifestations of society. The conceptualisation of the term has since been discussed in numerous disciplines ${ }^{1}$. The differentiation between tangible and intangible culture leads us to recognise the symbolic character of culture, in which symbols and meanings are the framework of social action and according to Geertz (1973, p. 89) culture is understood as "a system of inherited conceptions expressed in symbolic forms by means of which men communicate, perpetuate, and develop their knowledge about and attitudes towards life", as to say "a web of meanings". The analysis of culture must therefore be an interpretative science in search of these meanings, which for us are expressed through cultural artefacts and the social representations that society develops precisely about them.

In this respect, the concept of social representations - introduced into social psychology by Moscovici in the early 1960s - proves to be particularly valuable. This is because, as the following citation shows, the concept focuses on the elementary form of social knowledge (Araya Umaña, 2002; Schützeichel, 2007):

"Social representations [...] concern the contents of everyday thinking and the stock of ideas that
gives coherence to our religious beliefs, political ideas and the connections we create as spontane-
ously as we breathe. They make it possible for us to classify persons and objects, to compare and
explain behaviours and to objectify them as parts of our social setting" (Moscovici, 1988, p. 214).

Moscovici (1988) sees social representations as a component of social organisation that also frames the perception of individuals in relation to social structures and performative acts. The extent to which social reality is dependent on the particular framework of interpretation is made clear by the example of drug use. It can be perceived as a collapse of a family or a religious ceremony, as in several Mexican indigenous cultures. Consequently, social

\footnotetext{
See the article by Kroeber and Kluckhohn (1952) in which more than 164 definitions of the concept of culture were collected and summarised, as well as the discussion of the conceptualisation of the term culture in the context of indigenous cultures in Mexico by Mendoza et al. (2020).
} 
representations are always context-dependent and expressing the cultural values, beliefs and symbols. In addition, they represent dynamic entities that are constantly updated by performative acts. At the same time, social representations have a certain autonomy in the production of meaning (Moscovici, 1988; Schützeichel, 2007). In other words, social representations to a certain extent lead "a life of their own" (Moscovici \& Duveen, 2001). Moreover, social representations are attributed to the function of transforming the unknown into the familiar: The so-called process of "anchoring" (Moscovici, 1988; Araya Umaña, 2002).

Considering the fact that the concept of social representations unites pairs of opposites, it sometimes seems paradoxical. Social representations are stable with simultaneous instability, rigid and fluid, etc., which is why Abric (1993) divides them into a central core and peripheral elements. The peripheral elements refer to those aspects of social representations that are characterised by flexibility and mobility. Consequently, peripheral elements are directly related to an individual's experiences, and constitute an interface between the outside world and the central core. At the same time, they act as protective shields, preventing the central core, to a certain extent, from change. For example, repetitive experiences or profound impacts that deviate from the central core may change it. In general, however, the central core of social representations is characterized by relative stability ${ }^{2}$.

However, the concept is not limited exclusively to those social representations "which are formed by the medium of language" (Schützeichel, 2007, p. 451; translation by the authors), but increasingly considers visual knowledge as well as the material world and the artefacts existing in it (Moscovici, 1988; Schützeichel, 2007). Artefacts are objects that are created, used, or modified by means of human action (Lueger \& Froschauer, 2018). In other words, "artefacts as materialized products of human action [...] embody objectivations of social relations and social conditions; they represent the activities by which they were created" (Lueger, 2010, p. 92; translation by the authors). Accordingly, artefacts are - consciously or unconsciously - placed in the material world by humans and form part of the tangible culture. However, their creation does not remain without consequences in the social world either but has an effect on the thoughts and interaction of individuals as externalisation of humans (Lueger, 2010; Lueger \& Froschauer, 2018). Consequently, people live in a material world, which is partly created by them, but also influences their social world and vice versa (see following figure).

\footnotetext{
2 Against the background of the relatively stable constitution of the central core, Abric (1993) recognizes a certain connectivity to the approach of collective memory. According to Erll (2017), this concept has become one of the most widely discussed in cultural studies memory research. Assman's (1988) concept of collective memory is constituted by communicative and cultural memory. In this context, however, the approach of collective memory will not be discussed further.
} 


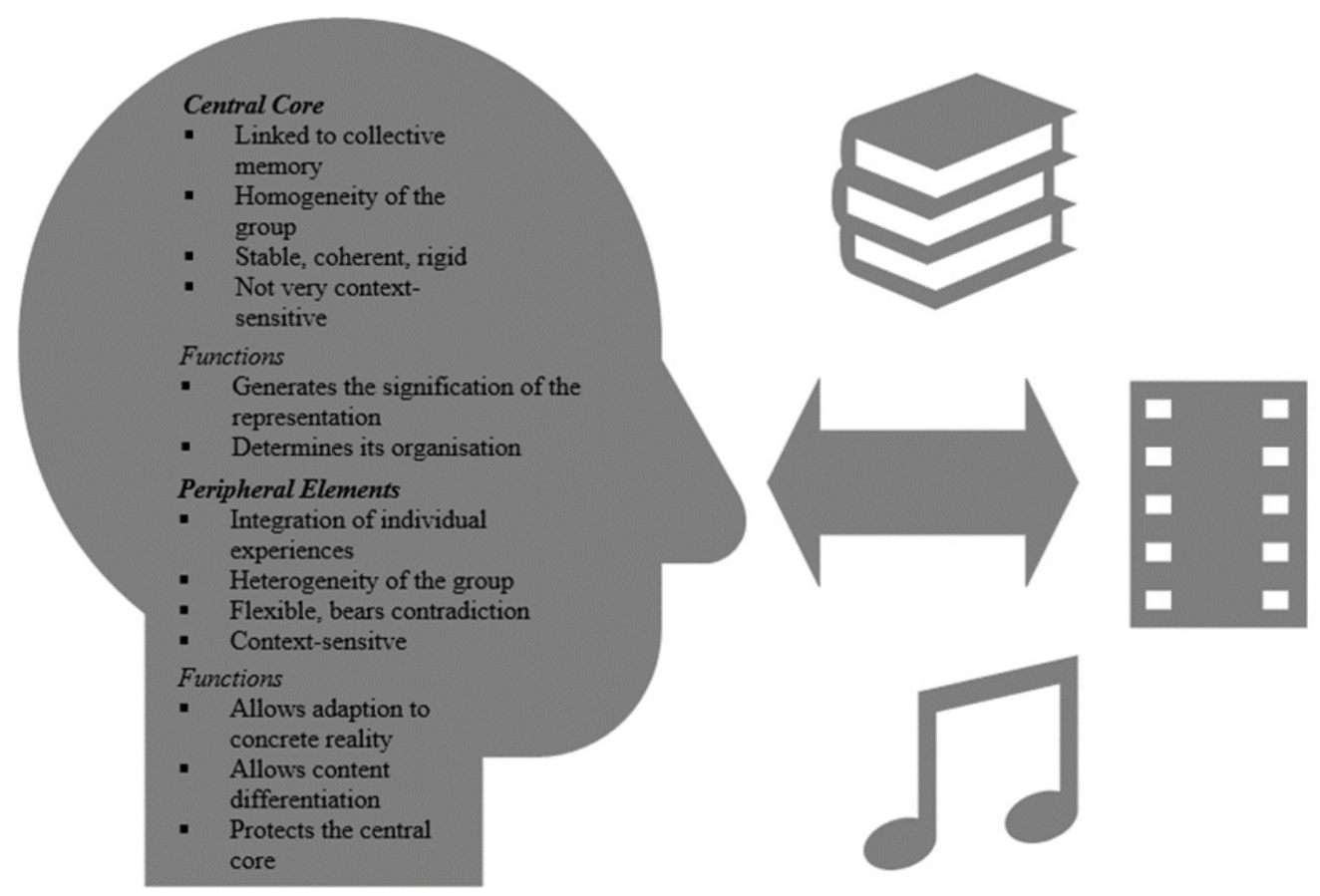

Figure 1: Reciprocity Between Individuals and Artefacts (own elaboration according to Abric, 1993)

Given the demonstrated interaction between social representations and produced artefacts, the social relevance of artefacts is undeniable. Accordingly, social distinction can be established through dress codes, value systems or the meaning of non-academic work can be manifested in different types of cultural artefacts. Given their prominent social relevance, the inclusion of artefacts in social analyses is important. Even more, a broader understanding of culture and society is only possible through a combination of language-based methods, like interviews, and artefact analysis (Lueger \& Froschauer, 2018). A study of cultural artefacts can provide clues to the patterns as well as the central core of social representations of a society composed of individuals of all ages. This was done for the cultural context of Mexico. The methodological approach will be described in the following section. 


\section{Methodical Approach}

The artefact analysis proceeds along four phases (see Figure 2).

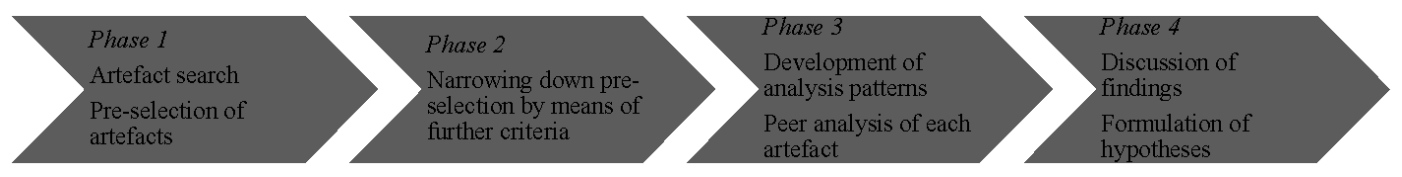

Figure 2: Working Process of the Artefact Analysis (own elaboration)

In the first phase, a pre-selection of cultural artefacts as social representations of nonacademic work took place. In the context of this study, cultural artefacts are primarily understood as those that transport narratives or forms of representation of non-academic work, such as films, murals, songs, etc.; however, tools from working contexts are not considered as cultural artefacts. The search was not limited to a specific type of cultural artefact because there was ex-ante uncertainty about whether and to what extent the topic of non-academic work could be found in artefacts. In this regard, Mexican film rankings, studies, etc. were included. For example, based on the 2017 study Estudio de Consumo de Medios y Dispositivos entre Internautas Mexicanos ${ }^{3}$ (IAB, 2017), the artefact type of Memes was also included in the analysis. The cultural artefacts found were screened to see if they contained representations of work. So far, 77 artefacts have been sighted, which, after a pre-selection within the international research group, were subjected to further investigation and discussion to ensure that only artefacts significant for the purpose of the study were analysed, leading to the second phase of artefact analysis.

In the second phase of work, the artefacts to be analysed were narrowed down further. Thus, not only non-academic work in general should be represented, but particularly the areas of administration, gastronomy, tourism, and metallurgy. This is in line with Lueger and Froschauer (2018), who postulate that the selection of artefacts must be significant for answering the research question. Another criterion is related to the production of the respective artefact. Accordingly, a person originally from Mexico (or someone intimately familiar with Mexico) had to have produced the artefact; this was to ensure that the representation of non-academic work was framed according to the cultural context. Other selection criteria that were applied to the analysis material are listed below, whereby these can partly occur in combination, but must at least be contained individually.

\footnotetext{
3 Study of media consumption and devices between Mexican Internet users (IAB,2017)
} 
The artefact:

- Has a certain reach,

- Recurs in other contexts (recurrence),

- Has intertextual passages,

- Is up-to-date, or

- Occupies a place in the collective memory.

After filtering the 77 artefacts according to these criteria, 44 remained. Table 1 gives an overview over the types of artefacts included into the analysis.

Table 1: Types of Analysed Artefacts (own elaboration)

\begin{tabular}{|c|c|c|}
\hline Artefacts & Category & Total \\
\hline Movies & $\begin{array}{l}\text { Comedy } \\
\text { Drama }\end{array}$ & 8 \\
\hline Documentaries & Cultural & 5 \\
\hline Series & Comedy & 7 \\
\hline Literary novels & Drama & 4 \\
\hline Memes & $\begin{array}{l}\text { Urban Myths } \\
\text { Parody } \\
\text { Mexican culture }\end{array}$ & 3 \\
\hline Songs & $\begin{array}{l}\text { Ranchera/Cumbia } \\
\text { Hip-pop }\end{array}$ & 2 \\
\hline Murals & History & 8 \\
\hline Monument & Historical & 1 \\
\hline Blog & Cultural & 1 \\
\hline Talk-show & Cultural & 1 \\
\hline Compendium Proverbs & Cultural & 1 \\
\hline Essay & Books & 2 \\
\hline Tele-Novela & Drama & 1 \\
\hline Total & & 44 \\
\hline
\end{tabular}

Due to diversity and heterogeneity of artefacts, it was necessary to develop different analysis patterns in the third phase. In this respect, the elaboration of the analysis patterns was guided by the key questions proposed by Lueger and Froschauer (2018) regarding the artefact's conditions of existence, the everyday contextual embedding of the meaning, distanced structural and descriptive analyses. Furthermore, reference was made to the German concept of Beruf, which served as a contrast to non-academic work (Clement, 1999b; Kutscha, 2008; Matthes 
\& Vicari, 2018), also making reference to Pries' (2010) conceptual reflections on the field of gainful employment. The comparison of non-academic work with the aforementioned German concept revealed differences that formed the starting point for generating specific questions that were added to the analysis pattern. In addition, depending on the type of artefact, we borrowed from other disciplines in some cases. For example, art scientific methods offered an adequate frame for analysing and interpreting e.g. murals (Held \& Schneider, 2007). Figure 3 depicts an example of an analysis pattern for cinematic material. Finally, in the third phase, the analysis was done on the basis of the developed patterns.

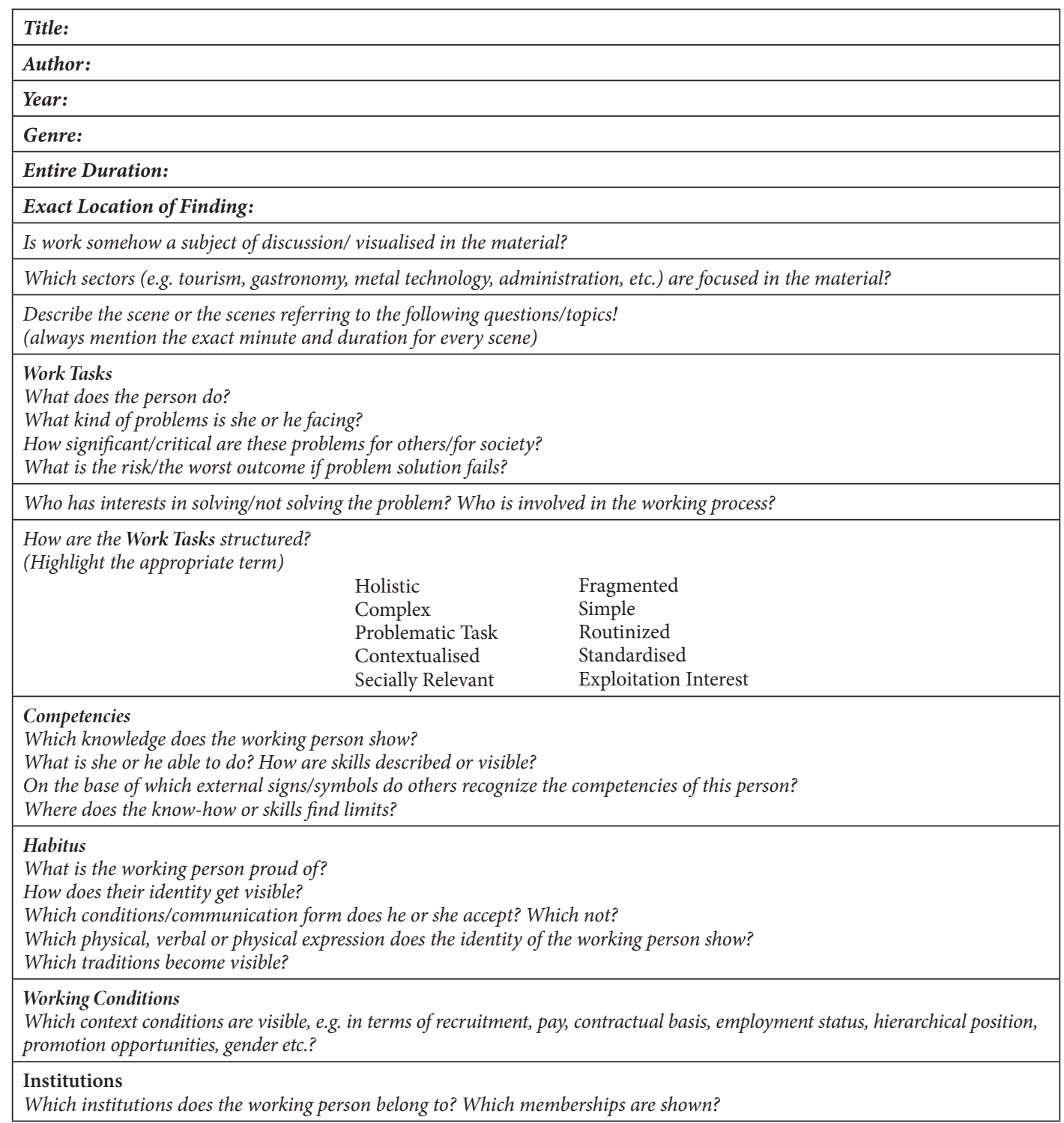

Figure 3: Example of an Analysis Pattern for Cinematic Material (own elaboration) 
The perception of each individual (i.e. the subjective constructions of reality) is dependent on cultural as well as social positions and other factors such as age, gender, etc., while these aspects are hardly reflected in everyday life. There is a term in the scientific field that describes this phenomenon: Situatedness ${ }^{4}$ (Kleemann et al., 2009). However, the phenomenon of situatedness does not only affect individuals outside the field of science, but also researchers. Consequently, at least two members, male and female, of the project team conducted the analysis of each artefact.

The analysis in teams of two was followed by the fourth phase, in which the processed patterns of analysis were discussed. Five to seven people regularly took part in the research group setting ${ }^{5}$, with at least half of the participants coming from the respective cultural context, while the rest were from outside the context. In this way, blind spots resulting from situatedness could be eliminated or at least mitigated (Kleemann et al., 2009). Within the research group, narratives were reflected and hypotheses about the social representations of non-academic work were discussed and scrutinized. The assumption was that repetitive narratives, behaviours, etc. refer to socially shared knowledge and thus expose the central core of social representations.

\section{$6 \quad$ Findings}

Based on the analysis of our sample of 44 artefacts, we present and discuss its findings through a selection of cultural artefacts that have proved particularly telling regarding the perception of non-academic work in Mexico. The findings are presented along the categories of habitus, competences, and working conditions, as reflected in the analysis pattern (Figure 3). These three categories could be best illuminated by the analysis of our sample of cultural artefacts. Because of the findings' tentative and preliminary character, follow-on research will have to elaborate, corroborate, refute or refine them.

For the category of habitus, it showed that everyday language gives many hints regarding social representations within Mexican culture. Known expressions and phrases result from a mix of cultures which have formed the idiosyncrasy of Mexicans over time. Mexicans use innumerable phrases to express all types of emotions and actions, although there are some expressions that are used more or less according to the social class or environment of a particular person. With good humour and typical eloquence, regardless of age, gender or race, Mexicans often express their views and perceptions with phrases that they only understand. The most recurrent and emblematic phrase to represent work in Mexico is chamba ${ }^{6}$; that is

\footnotetext{
${ }_{4}$ Original German term: Standortgebundenheit.

5 Besides the authors, Allistair Fritz López Mercado and Francisco Padilla Reyeros participate in this group.

6 Chamba is used colloquially to call for a job in Central America, Ecuador and Mexico. One of the most widespread versions states that its origin dates back to the 1940s when the governments of Mexico and the United States reached a temporary agreement: Mexicans would go to work in U.S. fields, where men were scarce due to that country's participation in World War II. The treaty lasted from 1942 to 1964 (Ramos y Duarte, 1898).
} 
to say the Mexican is not going to work, "but is going to chamber", not looking for work, but looking for chamba. In contrast to the more physical and informal chamba, academic work may be connoted with self-fulfilment, autonomy, a better standing in the social and organisational hierarchy or personal development. Meanwhile, non-academic labour in Mexican society is mainly seen as medium to survive in an often risky environment and is correspondingly less prestigious.

With respect to the positioning in the field of gainful employment, it becomes apparent that higher positions are, so to speak, hereditary and consequently tend to be reserved for individuals of higher social classes. In the film "Mirreyes vs. Godinéz", most employees, except for the protagonist (a young hard-working deputy director), accept this logic. When the owner dies unexpectedly, the son - without ever having worked, not to speak of having worked in that particular company - becomes the managing director or, colloquially, the patró $n^{7}$. There seems to be a heavenly given order of things that provides every human being their position. Good workers will humbly accept this position and place: "Dónde manda el capitán, no gobierna marinero ${ }^{8 "}$. The expression "ser ubicado", is widespread and often been used to describe a person's good character. In such a predetermined world, there is little point in being in a rush. "No hay que comprar el fuete, antes que el caballo"10", and "no por mucho madrugar, amanece más temprano ${ }^{11 "}$.

Overall, the analysed artefacts indicate limited promotion opportunities. In this respect, individuals might feel resigned to a certain extent, which could have a demotivating effect. Especially non-academic work is perceived as a necessary, but laborious fact of life. Proverbial wisdom tells people to stay in their jobs even if it is linked to hardship, because having a job is precious in order to make ends meet. Even if payment is bad, the proverb says "Cuando puedas trabajar, no lo dejes, aunque no te den lo que mereces ${ }^{12 "}$. This narrative is also taken up in other artefacts such as Roberto Bolaño's novel "Los Detectives Salvajes" and many of the analysed movies. As a result, the characters pursue the work activity out of material constraints, which means a purely pragmatic perspective of work.

Humour is a very telling cultural expression; by breaking expectations and rules it gives us important hints about what those implicit regularities are. If Cantinflas (a very well-known Mexican comedian from the 1950/60s, deeply anchored in the collective memory) is shown as a person who constantly avoids work and only accepts it in economic crises, he will gain the sympathy of all the people who feel they work for the money and not much else. In the famous series of "El Chavo del Ocho" from the 1970/80s, one of the main characters, Don

\footnotetext{
7 According to the Real Academia Española (2020), Patrón means; m. and f. Defender, protector. The word Patrón is culturally embedded in the Mexican context and is seen as a protector or paternal figure in companies.

8 Where the captain is ruling, the sailor will not.

9 Know what her or his place is.

${ }_{10}$ You do not have to buy the fort before the horse.

${ }^{11}$ No matter how early you get up, the sun won't rise.

12 If you can work, do not leave it, even if they do not give you what you deserve.
} 
Ramón, prefers to hide when the landlord comes to collect the rent rather than work and pay it off. Apart from the fact that it is an older series, the figure Don Ramón seems to be emblematic of the attitude and the avoidance of work. This is also illustrated by numerous Memes in circulation that take up this character in the light of such work topics. On the one hand, this fact underpins the assumption that some series, even though they are older, still have a certain actuality and are deeply anchored in the collective memory. On the other hand, it supports our thesis that the core of social representations on non-academic work are relatively stable and anchored in Mexican society, to which all age groups belong, also youth. Consequently, such cultural artefacts have descriptive and explanatory power with regard to the attitudes, thoughts and ideas of young people towards non-academic work.

While the character of Don Ramón is regarded with sympathy and a wide feeling of understanding, there are other people who avoid work, just because they can. In the more recent movies like "Nosotros los Nobles" or "Mirreyes vs. Godinez", it is clear that employment will be avoided, if social status allows it. Interestingly, there is an established term in Mexican society for the rich children of the Mexican economic elite, as the second film suggests: Mirreyes (meaning as much as my kings). The circulating narratives about the so-called Mirreyes tend to be negatively framed. Thus, they appear unpleasant, lazy and with a certain lack of empathy towards less well-situated people. However, the narratives show a change at the point where there is a need for the Mirreyes to work seriously. Through the work, they experience the moment of catharsis, so to speak, because the Mirreyes discard their attitudes, a habitus transformation takes place, which causes a change in culturally embedded values. And in the end, they also show solidarity with people from lower social classes.

As for the category of competences, we identified that being diligent, skilled and experienced comes to be one well-recognised way to maintain dignity in work. Like in many European cultures, we find proverbs about the importance of practice and perseverance in learning a trade. "La práctica hace al maestro"13" or "más sabe el diablo por viejo, que por diab$l o^{14}$ ". Being competent in Mexican society also includes the ability to manage difficult situations, improvising and finding solutions in nearly impossible situations. Improvisation plays a prominent role in Mexico's everyday life and work contexts. Films like "Grand Hotel I" or "Nosotros los Nobles" show with a lot of humour how Mexicans get out of difficult situations by accepting jobs, even in informality, and taking the most unlikely chances to improvise.

In terms of working conditions, many proverbs show physical work as demanding and dirty, in multiple ways comparing it with the duties of donkeys. In a society with a colonial background, which in important parts was shaped by large-scale agronomy and a sharp division between landowners and workers, the strict hierarchies are still perceptible today. These crystallise in numerous artefacts, such as in the movies "Roma" or "Buenos días Acapulco".

\footnotetext{
${ }^{13}$ Practice makes the expert.

14 The devil knows more from age than from being a devil.
} 
However, other artefacts, such as the murals of the artist Diego Rivera, focus on egalitarian social utopias, which propagate the breaking up of these anachronistic social structures while at the same time heroizing the worker. This kind of representation, however, is directly related to the ideology of the artist - he was an avowed communist.

Thus, despite some exceptions, strict hierarchies are evident in most artefacts. They also manifest themselves in the dressing habits of the people. In the cultural context of Mexico, however, the hierarchies also manifest themselves through the medium of language. This becomes clear from the colloquial terms patrón and peón. The term patrón, which is a traditional expression for a landowner, is even valid in the contemporary labour market, where almost every boss or company owner is still called patron.

In addition to the perceived hierarchies at the social and organisational level, it is striking that ascension within these is only possible, if at all, under difficulty. Moreover, filling higher positions within a company appears to be less based on meritocratic principles. Instead, it can be observed that the degree of kinship, including the for Mexican culture very important ritual kinship, described by Pries (2010) as compadrazgo-system, and gender play prominent roles. Another aspect which, up to a certain point, leads to promotion within the company seems to be the length of time they have been with the company. Consequently, the principle of seniority applies alongside the degree of kinship.

In Mexico, the culture of labour seems to be strongly embedded in social networks. A lot of proverbs about reciprocity and loyalty talk about favours. "Entre bomberos no se pisan las mangueras ${ }^{15 "}$ or "tú que sabes y yo que sé, cállate tú que yo me callaré16" are well known advices in Mexican society. The line between loyalty and complicity appears to be thin. Social networks also appear to be of immeasurable value in the recruitment and employment of personnel. In the novel "Los Detectives Salvajes" it is noticeable in various passages that a few characters in the novel tend to activate family, friends and/or acquaintances when looking for work. By means of social networks, the transition to a working relationship appears to be easier and more promising. The relevance of social capital on the threshold of employment seems to be enormously high. Furthermore, it is clear from the film "Nosotros los Nobles", for example, that the recommendations made mean double protection for the employer, as he or she has two contact persons at the same time. This increases social pressure and reduces possible misconduct of the newly hired employee. The phenomenon of social pressure is visible in numerous scenes of this film. When the female character (formerly a rich daughter) complains about the poor working conditions at the beginning of her employment, the person who recommended her holds her back. Furthermore, the recommender demands humility and gratitude for having given her a job in the first place that she has a job at all. She then rows back and accepts the poor working conditions. These are such that she recei-

\footnotetext{
${ }^{15}$ Between firemen, you do not step on the hoses.

${ }^{16}$ When you know and I know, you shut up and I'll shut up.
} 
ves no basic salary and works only on the basis of tips. There is also no written employment contract, which could indicate that this is a normality assumption regarding non-academic work in Mexico. Apart from the employment conditions mentioned above, the female film character is obliged to wear a work uniform. She dislikes this very much, as the women's uniform, unlike the men's uniform, is quite provocative. This observation can also be made for other artefacts. According to this, differences between the sexes are manifested in terms of dress practices in the realm of work. For women, the principle of "sex sells" is therefore particularly common.

Besides the aforementioned dress practices, gender stereotypes play a strong role not only in cultural artefacts but also in Mexican everyday language. The frequent use of sexualised and sometimes cruel language to describe social positions or characterise situations, for example as the colloquial terms chingón $n^{17}$ for good or chingada ${ }^{18}$ for bad - as the novel "El Laberinto de la Soledad" of Octavio Paz states - may bewilder foreigners strongly. In cultural artefacts about labour, women are often shown as physically attractive, but rather useless in their job, or - on the contrary - overly dedicated to work and by this way neglecting private lives and partnership. In the film "Loca por el Trabajo" a working woman is successfully promoted, but harshly criticised of being too ambitious and "crazy for work". Although she is successful in her job and has achieved financial independence, she is considered a loser after her husband leaves her. This highlights the pressure on her to perform as perfectly as possible in all roles. This refers to her roles as a passionate wife, loving mother, etc. In view of these numerous demands, the protagonist can only fail. What is astonishing, however, is that her male former colleague, who works just as much as she does, is not abandoned by his wife and perceived as a winner.

\section{Discussion and Conclusions}

The assumption that cultural artefacts, through their omnipresence in the material world, shape the attitudes and social representations of people in a society, including those of young people, is the starting point for this study. At the same time, cultural artefacts can be understood as reconstructions of reality that provide information about the patterns of perception of their producers. For this reason, one criterion for analysing the artefacts is that they were produced by people closely connected to the cultural context of Mexico. Interestingly, most of the analysed artefacts featuring forms of representation and narratives about nonacademic work were created almost exclusively by persons of male gender. For this reason, a predominantly male-framed perspective on the object of non-academic work opened up, which on the one hand can be read as a weakness of the artefact analysis conducted. On the

\footnotetext{
17 Violator.

${ }^{18}$ Violated.
} 
other hand, the low female presence in relation to the subject matter also reflects, in a certain way, the low participation of women in the formal labour market in Mexico. For example, according to OECD (2019), Mexican women are significantly less involved in formal employment than men. Moreover, females are significantly more likely to be neither enrolled in the education system nor in employment or training (NEET). Overall, the aspect of machismo prevalent in Mexico has not gone unnoticed in the forms of representation and narratives on non-academic work, as numerous artefacts contain and reproduce gender stereotypes.

As already described, it is assumed in this context that narratives and forms of representation in relation to non-academic work can give an indication of the cultural imprints and normality assumptions towards the object of study. Based on the findings presented here, it is possible to make some preliminary hypotheses about the social representations prevalent in Mexican society that affect the young population. For example, young people might perceive non-academic work as relatively unattractive because it is often informal, implying a lack of security, poor wages, etc. Furthermore, the representations and narratives show that, apart from office work, non-academic work is physically demanding but cognitively unchallenging. In terms of access to a company and promotion, social networks seem to have enormous relevance - the so-called compadrazgo-System (Pries, 2010) is often visible. Hierarchies seem rigid and opportunities for promotion limited. However, a narrative with more positive attributions regarding non-academic work can also be identified, which state that young people experience a habitus transformation through work. Nevertheless, non-academic work in Mexico seems to lack prestige, which could also have an impact on young people's educational and career aspirations and choices. This could mean that those who can afford it prefer to pursue a career in tertiary education rather than opt for a TVET programme. At the macro level, for example, the aforementioned lack of reputation could hamper attempts to implement such programmes, even though the training programmes are seen as offering great potential at many levels (OECD, 2019).

With the help of artefact analysis, interesting insights into culturally anchored social representations can be gained, whereby the forms of representation of non-academic work become visible in different depths. Regarding the method, it can be said that artefact analysis seems to be a good way to approach a new field of work or an unknown cultural context. However, the representations and narratives refer to the perspective of those social actors who are in certain positions of power and can therefore make themselves heard in the chorus of cultural artefacts. In summary, artefact analysis offers an interesting approach to a research object, but like any method, it has limitations, which can, however, be partially overcome in combination with other methods such as biographical interviews. 


\section{Acknowledgement}

This paper is based on the project "Cultural Practice of Non-Academic Work in Mexico" (Kulturelle Praxis nichtakademischer Arbeit in Mexiko - KuPraMex) funded by the German Federal Ministry of Education and Research (BMBF) (funding code 01BF18004A). We thank Allistair Fritz López Mercado and Francisco Padilla Reyeros for their continuous, valuable support to the research project.

\section{References}

Abric, J. C. (1993). Central system, peripheral system: Their functions and roles in the dynamics of social representations. Papers on Social Representations, 2(2), 75-78. https://psr.iscte-iul.pt/index. $\mathrm{php/PSR/article/view/126}$

Almeida, R., Anazawa, L., Menezes F., \& Vasconcellos, L. (2015). Investing in technical and vocational education and training: Does it yield large economic returns in Brazil? Policy Research Working Paper, 7246. World Bank. https://openknowledge.worldbank.org/handle/10986/21861

Araya Umaña, S. (2002). Las representaciones sociales: Ejes teóricos para su discusión [Social representations: Theoretical axes for discussion]. Cuaderno de Ciencias Sociales, 127. FLACSO.

Arnold, R. (1989). Berufsbildung in Lateinamerika [Vocational training in Latin America]. International Review of Education, 35(2), 159-177. https://www.jstor.org/stable/pdf/3444425.pdf?refreqid=e xcelsior\%3Ae9e8f4df6b145f371f8c12b3c987735f

Assmann, J. (1988). Kollektives Gedächtnis und kulturelle Identität [Collective memory and cultural identity]. In J. Assmann \& T. Hölscher (Eds.), Kultur und Gedächtnis (pp. 9-19). Suhrkamp. https://archiv.ub.uni-heidelberg.de/propylaeumdok/1895/1/Assmann_Kollektives_Gedaechtnis_1988.pdf

Bayón, M. C. (2008). Konturen des informellen Sektors in Mexiko und Argentinien [Contours of the informal sector in Mexico and Argentina]. In D. Boris, T. Gerstenlauer, A. Jenss, K. Schank \& J. Schulten (Eds.), Sozialstrukturen in Lateinamerika. Ein Überblick (pp. 147-170). VS.

Becker, R. (2004). Wandel der Sozialstruktur von Erwerbsverläufen [Change in the social structure of employment histories]. In F. Behringer (Ed.), Diskontinuierliche Erwerbsbiographien. Zur gesellschaftlichen Konstruktion und Bearbeitung eines normalen Phänomens (pp. 59-70). Schneider.

Behringer, F. (2004). Diskontinuierliche Erwerbsbiographien. Zur gesellschaftlichen Konstruktion und Bearbeitung eines normalen Phänomens [Discontinuous employment biographies. On the social construction and processing of a normal phenomenon]. Schneider.

Bourdieu, P. (1993). Sociology in Question. Sage.

Brose, H., \& Wohlrab-Sahr, M. (2018). Arbeit und Biografie [Work and biography]. In H. Lutz, M. Schiebel \& E. Tuider (Eds.), Handbuch Biografieforschung. (pp. 485-497). Springer.

Cáceres-Reebs, D., \& Schneider, U. (2013). Berufsausbildung in Mexiko. Wie das Land das duale Modell tropenfest macht [Vocational education and training in Mexico - How the country has tropicalised the dual model]. Berufsbildung in Wissenschaft und Praxis (BWP), 5, 11-16. https://www. bwp-zeitschrift.de/de/bwp.php/de/bwp/show/7133

Cameron, K. S., \& Quinn, R. E. (2006). Diagnosing and changing organizational culture. Based on the competing values framework. Jossey-Bass. 
Cillo, V., Garcia-Perez, A., Del Giudice, M., \& Vicentini, F. (2019). Blue-collar workers, career success and innovation in manufacturing. Career Development International, 24(6), 529-544. https://doi. org/10.1108/CDI-11-2018-0276

Clement, U. (1999a). Politische Steuerung beruflicher Bildung. Die Bedeutung unterschiedlicher Entwicklungslogiken für die Berufsbildungspolitik in Ländern der Dritten Welt am Beispiel Chile [Political governance of vocational education and training. The significance of different development logics for VET policy in Third World countries, taking Chile as an example]. Nomos.

Clement, U. (1999b). Die transnationale Kommunizierbarkeit des Berufs: Verständigungsprobleme im globalen Dorf [The transnational ability to communicate the concept of Beruf: Communication problems in the global village]. Zeitschrift Für Pädagogik, Beiheft 40, 209-231.

Clement, U. (2016). Nationale Qualifikationsrahmen zwischen Aufbruch und Institution [National qualification frameworks between departure and institution]. In H. Altrichter (Ed.), Handbuch Neue Steuerung im Schulsystem (pp.439-454). Springer.

Clement, U., \& Oelsner, V. (2016). Was macht Schule? Schule als gestalteter Raum [What does school do? School as a designed space]. Springer.

Curchod, C., Patriotta, G., Cohen, L., \& Neysen, N. (2019). Working for an algorithm: Power asymmetries and agency in online work settings. Administrative Science Quarterly. https://doi. org/10.1177/0001839219867024

Deißinger, T., \& Frommberger, D. (2010). Berufsbildung im internationalen Vergleich. Typen nationaler Berufsbildungssysteme [Vocational education and training in international comparison. Types of national vocational training systems]. In R. Nickolaus, G. Pätzold, H. Reinisch \& T. Tramm (Eds.), Handbuch Berufs- und Wirtschaftspädagogik (pp. 343-348). Klinkhardt. https://d-nb.info/1113109610/34

Elsbach, K. D. (2003). Relating physical environment to self-categorizations: Identity threat and affirmation in a non-territorial office space. Administrative Science Quarterly, 48, 622-654.

Erll, A. (2017). Kollektives Gedächtnis und Erinnerungskulturen: Eine Einführung [Collective memory and memory cultures: An introduction] (3rd ed., revised). J.B. Metzler. https://doi.org/10.1007/9783-476-05495-1

Geertz, C. (1973). The Interpretation of cultures. Basic Books.

Georg, W. (1997). Kulturelle Tradition und berufliche Bildung. Zur Problematik des internationalen Vergleichs [Cultural tradition and vocational training. The problem of international comparison]. In W.D. Greinert, W. Heitmann, R. Stockmann \& B. Vest (Eds.), Vierzig Jahre Berufsbildungszusammenarbeit mit Ländern der Dritten Welt. Die Förderung der beruflichen Bildung in den Entwicklungsländern am Wendepunkt? (pp.65-94). Nomos.

Giesecke, J., \& Wotschack, P. (2009). Flexibilisierung in Zeiten der Krise. Verlierer sind junge und gering qualifizierte Beschäftigte [Flexibility in times of crisis. Young and low-skilled workers are the losers]. WZBrief. https://bibliothek.wzb.eu/wzbrief-arbeit/WZBriefArbeit012009_giesecke_wotschack.pdf

Greinert, W.-D. (1997). Das Strategieproblem in der Berufsbildungszusammenarbeit und die Rolle von Wissenschaft und wissenschaftlicher Theorie [The strategy problem in vocational training cooperation and the role of science and scientific theory]. In W.-D. Greinert, W. Heitmann, R. Stockmann \& B. Vest (Eds.), Vierzig Jahre Berufsbildungszusammenarbeit mit Ländern der Dritten Welt. Die Förderung der beruflichen Bildung in den Entwicklungsländern am Wendepunkt? (pp. 53-64). Nomos.

Hall, C. C., Zhao, J., \& Shafir, E. (2014). Self-affirmation among the poor: Cognitive and behavioral implications. Psychological Science, 25(2), 619-625. 
Held, J., \& Schneider, N. (2007). Grundzüge der Kunstwissenschaft: Gegenstandsbereiche - Institutionen Problemfelder [Fundamentals of art studies: subject areas - institutions - problem areas]. UTB.

IAB México, Kantar Millward Brown, \& Televisa Digital. (2017). Generación Z: Estudio de consumo de medios entre internautas Mexicanos 2017 [Generation Z: Media consumption study among Mexican Internet users 2017]. https:/www.iabmexico.com/estudios/consumo-medios-2017-generacion-z/

Icardi, R. (2021). Returns to workplace training for male and female employees and implications for the gender wage gap: A quantile regression analysis. International Journal for Research in Vocational Education and Training, 8(1), 21-45. https://journals.sub.uni-hamburg.de/hup2/ijrvet/article/ view/506/293

INEGI (2020). Encuesta nacional de dinámica demográfica. INEGI Publishing. https://www.inegi.org. $\mathrm{mx} /$ programas/enadid/

Kahn, W. A. (2001). Holding environments at work. Journal of Applied Behavioral Science, 37(3), 260 279. https://journals.sagepub.com/doi/pdf/10.1177/0021886301373001

Kleemann, F., Krähnke, U., \& Matuschek, I. (2009). Interpretative Sozialforschung: Eine praxisorientierte Einführung [Interpretative social research: A practice-oriented introduction]. VS. https://doi. org/10.1007/978-3-531-91987-4

Kroeber, A. L., \& Kluckhohn, C. (1952). Culture: A critical review of concepts and definitions. Papers. Peabody Museum of Archaeology \& Ethnology, Harvard University, 47(1), viii, 223.

Kutscha, G. (2008). Beruflichkeit als regulatives Prinzip flexibler Kompetenzentwicklung - Thesen aus berufsbildungstheoretischer Sicht [Professionalism as a regulatory principle of flexible competence development - theses from a VET theory perspective]. Berufs- Und Wirtschaftspädagogik-Online, 14, 1-11. http://www.bwpat.de/ausgabe14/kutscha_bwpat14.shtml

Lauterbach, U. (1994). Schulische und betriebliche Berufsbildung im internationalen Vergleich [School and company-based VET in international comparison]. Bildung und Erziehung, 47(3), 237-248. https://doi.org/10.7788/bue.1994.47.3.237

Lehner, R. (1994). Struktur- und Gestaltungsprobleme der beruflichen Bildung in Lateinamerika. Dargestellt am Beispiel Ecuador [Structural and design problems of vocational training in Latin America. Presented by the example of Ecuador]. Lang.

Lueger, M. (2010). Interpretative Sozialforschung: Die Methoden [Interpretative social research: The methods]. UTB.

Lueger, M., \& Froschauer, U. (2018). Artefaktanalyse: Grundlagen und Verfahren. Lehrbuch [Artefact analysis: Principles and procedures. Textbook]. Springer VS.

Matthes, B., \& Vicari B. (2018). Arbeitsmarktorientierte Berufsforschung [Labour market-oriented occupational research]. In R. Arnold, A. Lipsmeier \& M. Rohs (Eds.), Living reference work. Handbuch Berufsbildung (pp. 1-12). VS Springer. https://doi.org/10.1007/978-3-658-19372-0 52-1

Mendoza, S., Raesfeld, L., \& López, S. (2020). Nuevos procesos de identidad en poblaciones indígenas: el caso del Catálogo de Pueblos y Comunidades Indígenas del estado de Hidalgo [New identity processes in indigenous populations. The case of the catalog of Indigenous communities of the State of Hidalgo]. In M. G. Galicia, K. H. Pizarro \& U. M. Romero (Eds.), Identidades en contexto, teorías, métodos y análisis de casos (pp. 191-220). UNAM.

Moscovici, S. (1988). Notes towards a description of social representations. European Journal of Social Psychology, 18, 211-250. https://doi.org/10.1002/ejsp.2420180303

Moscovici, S., \& Duveen, G. (2001). Social representations: Explorations in social psychology. New York University Press. 
Organisation for Economic Co-operation and Development OECD. (2019). OECD Economic surveys: MEXICO 2019. OECD Publishing. https://doi.org/10.1787/a536d00e-en

Oelsner, V., \& Richter, C. (2015). Bildung in Lateinamerika. Strukturen, Entwicklungen, Herausforderungen [Education in Latin America. Structures, developments, challenges]. Waxmann.

Pries, L. (2010). Erwerbsregulierung in einer globalisierten Welt. Theoretische Konzepte und empirische Tendenzen der Regulierung von Arbeit und Beschäftigung in der Transnationalisierung [Employment regulation in a globalised world. Theoretical concepts and empirical tendencies of the regulation of work and employment in transnationalisation]. Springer VS.

Ramos y Duarte, F. (1898). Diccionario de mejicanismos [Dictionary of xexicanisms]. Herrero Hermanos.

Real Academia Española. (2020). Diccionario de la lengua Española [Spanish language dictionary]. https://www.rae.es/drae2001/patr\%C3\%B3n

Sagiv, L., \& Schwartz, S. (2007). Cultural values in organizations. Insights for Europe. European Journal of International Management, 1(3), 176-190. https://doi.org/10.1504/EJIM.2007.014692

Santhanam, N., \& Srinivas, S. (2019). Modeling the impact of employee engagement and happiness on burnout and turnover intention among blue-collar workers at a manufacturing company. Benchmarking, 27(2), 499-516. https://doi.org/10.1108/BIJ-01-2019-0007

Schönstedt-Maschke, A. (2013). Armutsbekämpfung durch berufliche Bildung. Fallbeispiel SENATI/ Peru [Poverty reduction through vocational training. Case study SENATI/Peru]. In R. Öhlschläger \& H. Sangmeister (Eds.), Von der Entwicklungshilfe zur internationalen Zusammenarbeit (pp.113-126). Nomos.

Schützeichel, R. (2007). Soziale Repräsentationen [Social representations]. In R. Schützeichel (Ed.), Handbuch Wissenssoziologie und Wissensforschung (pp. 450-455). UVK.

Sevilla, M. P. (2017). Panorama de la educación técnica profesional en América Latina y el Caribe [Overview of vocational technical education in Latin America and the Caribbean.]. Serie Políticas Sociales.

Tylor, E. B. (1891). Primitive culture. Researches into the development of mythology, philosophy, religion, language, art and custom. Oxford.

Voß, G. (1998). Die Entgrenzung von Arbeit und Arbeitskraft. Eine subjektorientierte Interpretation des Wandels der Arbeit [The demarcation of work and labour. A subject-oriented interpretation of the change of work]. Mitteilungen aus der Arbeitsmarkt- und Berufsforschung, 31(3), S. 473-487. http:// doku.iab.de/mittab/1998/1998_3_MittAB_Voss.pdf

Wallenborn, M. (2001). Die berufliche Bildung in Lateinamerika [Vocational education and training in Latin America]. Europäische Zeitschrift Berufsbildung, 22, 62-73. https://www.cedefop.europa.eu/ files/22-DE.pdf

Wiemann, K. (2018). Mexiko [Mexico]. Budrich.

Wolf, S. (2011). Arbeitskultur und der Transfer von Berufsbildungselementen in andere Länder [Work culture and the transfer of vocational training elements to other countries]. Zeitschrift für Berufs- und Wirtschaftspädagogik, 107(4), S. 543-567.

Wolf, S., Penton, F., Beltran Marin, A., \& Romero, O. (2011). The Cuban Vocational Education and Training System and its Current Changes. Journal for Critical Education Policy Studies, 9(1), S. 224-240. http://www.jceps.com/wp-content/uploads/PDFs/09-1-09.pdf 


\section{Biographical Notes}

Ute Clement is Full Professor and Holder of the Chair for Economical and Vocational Education at the University of Kassel (Germany) since 2003. She received her doctoral degree as well as her habilitation degree from the Faculty of Education of the University of Karlsruhe. Her research interests comprise educational government, cultural aspects of vocational education, and vocational biographies.

Paola Garcia Fuentes holds a $\mathrm{PhD}$ in Education Sciences from the Universidad Autonoma del Estado de Hidalgo (Mexico). Currently she is a collaborator in the research project $\mathrm{Ku}$ PraMex (Cultural Practice of Non-Academic Work in Mexico) at the Institute of Management and Business Studies (IBWL) of the University of Kassel (Germany), funded by the German Ministry of Education and Science (Bundesministerium für Bildung und Forschung, BMBF). Her research interests focus on knowledge transfer and education.

Stefan Gold is Full Professor and Holder of the Chair for Business Management with focus on Corporate Sustainability at the University of Kassel (Germany). Previously, he worked at the International Centre for Corporate Social Responsibility (ICCSR) of the University of Nottingham (United Kingdom) and at the Chair of Production and Logistics Management of the University of Neuchâtel (Switzerland). He received his doctoral degree from the Faculty of Economics and Management of the University of Kassel. His research interests comprise sustainability management, decent work, supply chain and operations management, humanitarian operations, and corporate accountability.

Claudia Hunink is a $\mathrm{PhD}$ Student in the Institute of Vocational Education (IBB) of the University of Kassel (Germany). Currently she is working on the interdisciplinary project named KuPraMex (Cultural Practice of Non-Academic Work in Mexico) financed by the German Ministry of Education and Science (Bundesministerium für Bildung und Forschung, $\mathrm{BMBF})$. Her research interests are centred on vocational education and training on an international level and on the topic of migration.

Lydia Raesfeld is Full Professor at Universidad Autónoma del Estado de Hidalgo (Mexico) at the Department of Educational Sciences and is member of the Mexican National System of Researchers. She holds a PhD in Ethnology from the Albert-Ludwigs-Universität, Freiburg (Germany). Her research interests focus on social and cultural studies in education, attending topics like education and intercultural competence, educational policy and the link between education, society, and work. At Universidad Autónoma del Estado de Hidalgo she has served as Coordinator of the Research and Graduate Division, as well as Director of the Science and Technology Park. 